http://kitaibelia.unideb.hu/

ISSN 2064-4507 (Online) • ISSN 1219-9672 (Print)

(C) Department of Botany, University of Debrecen, Hungary

27(1): 118-122.; 2022

DOI: $10.17542 /$ kit.27.010

short communication • rövid közlemény

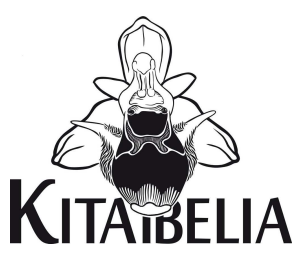

\title{
New occurrence of Myricaria germanica in a secondary habitat (NE Hungary)
}

\author{
KELECSÉnYI Péter ${ }^{*} *$ TAKÁCs Attila ${ }^{2,3}$
}

(1) H-3525, Miskolc, Mátyás király u. 108.; *kelepeti1@gmail.com (2) Debreceni Egyetem, TTK, Növénytani Tanszék, H-4032 Debrecen, Egyetem tér 1.

(3) ELKH-DE Természetvédelmi Biológiai Kutatócsoport, H-4032 Debrecen, Egyetem tér 1.

\section{A Myricaria germanica újabb előfordulása másodlagos élőhelyen}

Összefoglalás - Közleményünkben a Myricaria germanica (L.) Desf egy újabb, másodlagos élőhelyhez kötődő előfordulását ismertetjük Észak-Kelet Magyarországról, a Bükk hegység pereméről, egy miskolci salaklerakó területéről. A növény a salak kitermelése során kialakult meredek falon telepedett meg. A fal eróziója miatt időnként egy-egy tő onnan leszakad. Az elpusztult egyedek életkora az évgyűrüik alapján 5-13 év közötti. A körülbelül 50 töves populáció ma a legnagyobb (de talán az egyetlen) hazai állománya a fajnak. A salaklerakó területén további ritka és védett fajok is előkerültek (Epilobium dodonaei Vill., Dysphania botrys (L.) Mosyakin \& Clemants, Dryopteris carthusiana (Vill.) H.P. Fuchs, Polystichum aculeatum (L.) Roth ex Mert.).

Kulcsszavak: anemochoria, Bükk hegység, pionír élőhely, salaklerakó, Tamaricaceae, veszélyeztetett faj

Abstract - In this paper, we report a new occurrence of Myricaria germanica (L.) Desf in a secondary habitat from the north-eastern part of Hungary, from the edge of the Bükk Mountains, in a slag dump in Miskolc. The plant is established on a steep wall formed during the extraction of slag. Due to the erosion of the wall, occasionally a few plants fall off. The age of the dead specimens is between 5 and 13 years, based on their growth rings. The population of about 50 individuals is the largest (but perhaps the only) living population of the species in Hungary. Other rare and protected species (Epilobium dodonaei Vill., Dysphania botrys (L.) Mosyakin \& Clemants, Dryopteris carthusiana (Vill.) H.P. Fuchs, Polystichum aculeatum (L.) Roth ex Mert.) have also been found in the slag heap area.

Keywords: anemochory, Bükk Mts, endangered species, pioneer habitat, slag heap, Tamaricaceae, protected species

\section{Introduction}

False tamarisk (Myricaria germanica (L.) Desf.) is a shrub species with a highly fragmented Eurasian distribution area, mainly confined to the mountains (MEUSEL et al. 1978, SiTZIA et al. 2021). Its primary habitats are the gravel banks of fast-flowing rivers and streams carrying coarse sediment. In these habitats M. germanica is a characteristic or dominant species of the pioneer vegetation (cf. MuciNA et al. 2016). This habitat type has never been common in the current area of Hungary, and former populations of false tamarisk were known along rivers flowing from the Alps. The interventions to regulate the riverbeds have reduced its former extent. In addition, the rapid dynamics of the sediment accumulation and erosion make these 
banks suitable for the establishment of false tamarisk for only a relatively short period of time (cf. FENYŐSI \& HORVÁTH 1995).

Myricaria germanica is considered as near threatened (NT) species in the Carpathians (TURIS et al. 2014) and at a high risk of extinction in Hungary (KIRÁLY 2007, BARTHA 2019). A critical review of the distribution data of the species in Hungary can be found in KIRÁLY \& KIRÁLY (2018): in their opinion, some of the archive occurrence data on Myricaria are false, however, the plant has not been found for several years in its well-documented sites along the Danube and the Drava rivers.

Similarly to other riparian pioneer species, the emergence of false tamarisk in secondary habitats has long been known. The distribution map presented by MeuseL et al. (1978) shows several synanthropic occurrences in Scandinavia and Germany. More recently there are also reports of false tamarisk in secondary habitats from other parts of the distribution area (e.g. Csiky in KoRda 2010 from Romania, Michielon \& SitZia 2010 from Italy, NowaK et al. 2011 from Poland, MARINov et al. 2017 from Bulgaria).

In Hungary, the known secondary colonies of the species are concentrated in BorsodAbaúj-Zemplén county (NE Hungary). The first such case was documented by VIRóK et al. (2004) in Rudabánya, in an abandoned iron ore mine, where it has probably disappeared due to the progress of succession (Virók V. pers. comm.). SÜVEGES et al. (2017) found a single individual near Hejőpapi in a currently actively used gravel pit. This plant has also been destroyed by material handling (SÜVEGES et al. 2020). In this paper, we report on a recent discovery of a remarkable false tamarisk population in an anthropogenic habitat.

\section{Material and methods}

The study area is located on the eastern edge of the Bükk Mountains, near Miskolc, at the Sásas Valley (N 48.08599 ${ }^{\circ}$ E $20.69852^{\circ}, \sim 250 \mathrm{~m}$ a.s.l., CEU grid: 7990.1), in a slag depositing area, opening from the Tatar Ditch (Mexico Valley). The valley was used as a limestone quarry until 1954 and a slag mine from 1956 (Izsó 2011). The valley (including the mining yard) was filled with by-products of the iron and steel industry (mainly slag) in Diósgyőr, probably in the 1950s. The deposited slag began to be extracted as a secondary industrial raw material. This activity seems to continue to the present day, resulting the formation of steep, eroding slopes similar to those in opencast mines.

The first author made a field survey at the end of January 2021, when he found a large, hitherto unknown population of the false tamarisk (Myricaria germanica (L.) Desf.). Further field surveys were carried out in March and July 2021, when we surveyed the living individuals of the plant.

Ten of the dead (i.e. torn and falling from the crumbling walls) specimens were collected to determine their age based on their growth rings. M. germanica does not form a trunk but develops many above-ground branches from its base. These branches break off easily and the plant continually produce new shoots, thus, it is not sure that the thickest shoot represents correctly the age of a certain individual. Therefore, the growth rings of the collected individuals were examined on the cross-section of the root neck. The roots were sawed between the lowest branches of the above ground shoot system and the first branching of the root system. The cross-sectional surface has been sanded smooth with a P180 grit abrasive cloth to make the growth rings more visible. We also recorded the crosssectional diameter of the roots where the growth rings were counted.

During the field trip in July, we collected a flowering shoot, which has been deposited in the herbarium collection of the University of Debrecen (DE) as a voucher. 


\section{Results and discussion}

Although the vascular flora of the Bükk Mts is well explored generally, the work of VojTKó (2001) mainly reflects the research of the natural vegetation, so the study of secondary habitats may provide several floristic novelties (cf. SCHMOTZER 2015, SCHMOTZER et al. 2021). These include the discovery of Myricaria germanica from the slag heap of Sásas Valley in Miskolc.

Myricaria germanica was found on a steep, eroding slag slope, which is almost vertical (somewhere concave) and exposed to the south. Erosion of the wall occasionally causes the fall of some individuals.

The deposited slag shows horizontal stratification: the layers have different colors and degrees of friability (presumably due to their different composition). In the middle zone of an excavation, a $\sim 1.5-2 \mathrm{~m}$ width layer is visible, in which about 50 well-developed individuals of the Myricaria are rooted. During our visit in March, we observed that water was slightly seeping out of this layer (and only this layer), meaning that the underlying layer is presumably impermeable. In addition to the lack of competition of other plants on the slag slope, the water availability of this layer provides the conditions for the species to colonize here. In the same layer we also observed the presence of Tussilago farfara L. which is also a pioneer and water demanding species.

Based on the number of growth rings observed on the cross-section of the roots, the age of the collected individuals ranged from 5 to 13 years, with an average of 8 years (arithmetic mean), which roughly corresponds to the lower limit of the previously reported typical lifetime data of this species (cf. LENER 2011). According to LENER (l.c.), there is no close and general correlation between root thickness and age of the plant since the size of the annual rings formed is strongly influenced by the water supply of the growing site. However, our plants originate from the same place and developed under the same conditions, so in this case the root thickness and the number of annual rings correlate (Fig. 1).

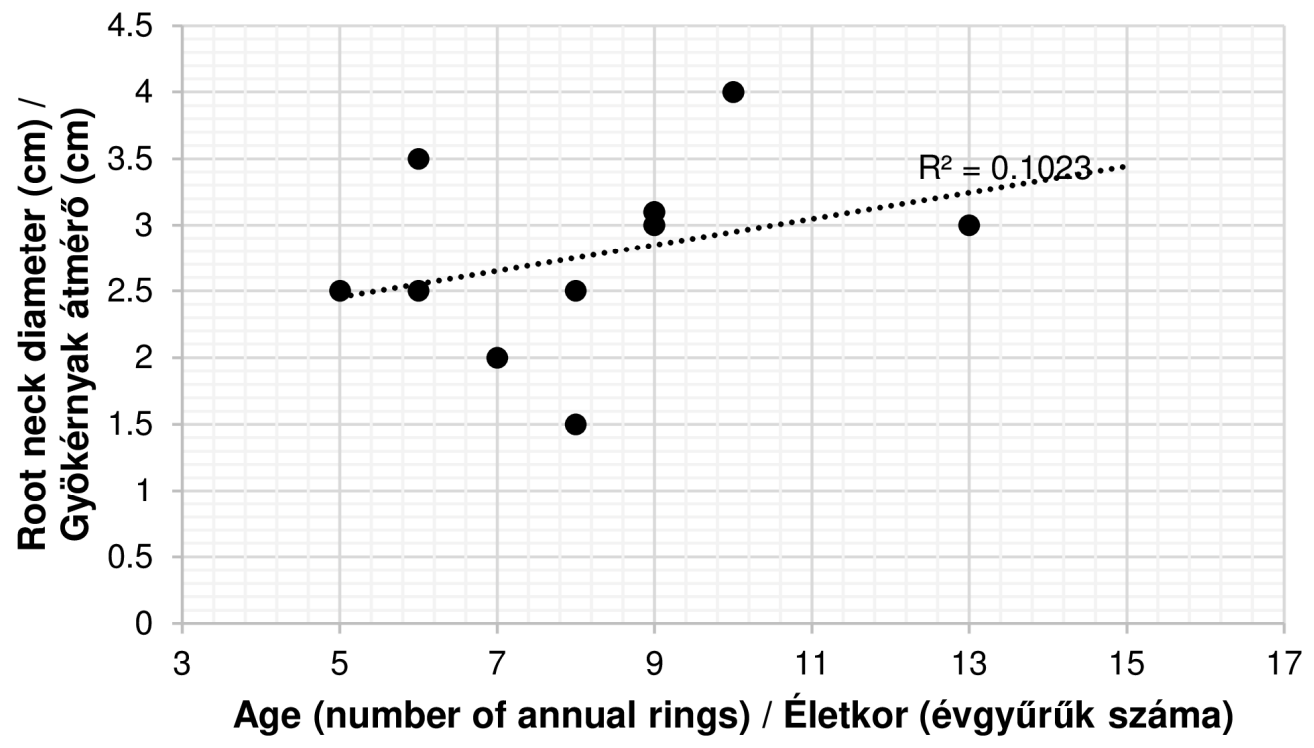

Fig. 1 Correlation of the root diameter and the age of the individuals 1. ábra A gyökér vastagsága és az egyed életkora közti összefüggés 
Epilobium dodonaei Vill. and Dysphania botrys (L.) Mosyakin \& Clemants are widespread on the pioneer surfaces of the slag deposit - these two species are known to be able colonize mines and spoil tips. In addition, partly alien weeds (Daucus carota L., Solanum nigrum L., Oenothera biennis L., Microrrhinum minus (L.) Fourr., Echium vulgare L., Phytolacca americana L., Erigeron annuus (L.) Desf., Solidago canadensis L., Artemisia vulgaris L., Picris hieracioides Sibth. \& Sm, Hibiscus trionum L., Calamagrostis epigejos (L.) Roth, Reynoutria ×bohemica Chrtek \& Chrtková), and in a smaller proportion, scattered individuals of drygrassland generalists (Reseda lutea L., Linaria genistifolia (L.) Mill., Salvia verticillata L., Centaurea stoebe L.) form a sparse vegetation. The colonizing woody plants are also partly aliens (Robinia pseudo-acacia L., Ailanthus altissima (Mill.) Swingle, Pinus spp.) or native pioneers (Betula pendula Roth, Frangula alnus Mill., Populus spp., Salix spp.). In the depressions, in the shaded areas and on the north-facing slopes, dense shrublands has developed (Sambucus nigra L., Cornus sanguinea L., Tilia cordata Mill., Acer campestre L.). In these shrublands and in the edge of the adjacent woods some individuals of Dryopteris carthusiana (Vill.) H.P. Fuchs, Polystichum aculeatum (L.) Roth ex Mert. and Gymnocarpium dryopteris (L.) Newman were found.

More recently, SCHMOTZER et al. (2021) documented the mass occurrence of Gypsophila perfoliata L. in another slag heap site (and in other industrial and urban habitats) in Miskolc. Interestingly, this species is absent from the Sásas valley, while the Epilobium dodonaei and Dysphania botrys were not found in the slag deposit of the Gálos area studied by SCHMOTZER et al. (l.c.). In addition to the differences of the relief and the microclimate of the locations, presumably there are also differences in the quality (composition) of the deposited materials, which may limit the range of species that can colonize.

The reproductive biology of Myricaria germanica was described by LENER (2011): the plants produce large quantities of anemochorous seeds, which mature over several months, so that propagules disperse over a long period and potentially over a large area. Despite this, the majority of the seedlings appears close to the fruiting specimens and has a very low survival rate. Taking into account the ability of the species to spread and colonization, the populations of Rudabánya, Hejőpapi and Miskolc are certainly related to each other by descent, and it cannot be excluded that the plant may occur on the sand- and gravel-banks of the Sajó and Hernád rivers or in other gravel pits of the Sajó-Hernád plain. However, the closest mass populations of the species are present in the northwestern Carpathians (NE of Slovakia) - presumably these are the primary propagule sources of the North Hungarian secondary colonization.

\section{Acknowledgements}

We are grateful to Ibolya Kelecsényi and Ágnes Kelecsényi Gombos for their help. We are thankful to Attila V. Molnár for his suggestion on the lifetime estimation of the dead plants, and to our reviewers for their useful comments. The work of Attila Takács was supported by the NKFI-OTKA K132573 and PD137828 grants.

\section{Literature}

BARTHA D. (2019): Vörös Lista. Magyarország veszélyeztetett fa-és cserjefajai. - Soproni Egyetem Kiadó, Sopron.

FENYősi L. \& HoRVÁTH Z. (1995): A csermelyciprusról. - Erdészeti Lapok 130(11): 350.

Izsó I. (2011): A Miskolci Bányakapitányság kerületének bányaipara. - Közhasznú Alapítvány a Borsodi Bányász Hagyományokért, Miskolc. 
KIRÁLY G. \& KiRÁLY A. (2018): Adatok és kiegészítések a magyar flóra ismeretéhez III. - Botanikai Közlemények 105(1): 27-96.

KIRÁLY G. (2007): Vörös Lista. A magyarorszagi edenyes flora veszelyeztett fajai. - Szerzői kiadás, Sopron.

KoRDA M. (2010): Csermelyciprus - Myricaria germanica (L.) Desv. In: BARTHA D. (szerk.), Magyarország ritka fa- és cserjefajai II. - Tilia 15: 139-148.

LENER F. P. (2011): Etablierung und Entwicklung der Deutschen Tamariske (Myricaria germanica) an der oberen Drau in Kärnten. - Thesis, University of Wien.

Marinov Y., Dimitrov D., Gussev C. \& PACHEDjIEva K. (2017): Current status, distribution and habitat of the threatened species Myricaria germanica (Tamaricaceae) in Bulgaria. - Bulletin of the Natural History Museum - Plovdiv 2: 21-28.

Meusel H., Jäger E., RAuSChen S. \& Wienert E. (eds) (1978): Vergleichende Chorologie der Zentraleuropäischen Flora: Karten. - VEB Gustav Fischer Verlag.

Michielon B. \& Sitzia T. (2010): Presenza di Myricaria germanica (L.) Desv. lungo il torrente Avisio (Trentino, Italia Settentrionale). - Annali Museo Civico Rovereto 26: 319-346.

Mucina L., Bültmann H., Dierßen K., Theurillat J. P., Raus T., ČARni A., ... \& TichÝ L. (2016): Vegetation of Europe: hierarchical floristic classification system of vascular plant, bryophyte, lichen, and algal communities. - Applied Vegetation Science 19: 3-264.

NowAK T., URBisZ A., KAPUSTA P. \& TOKARSKA-GUZIK B. (2011): Distribution patterns and habitat preferences of mountain vascular plant species in the Silesian Uplands (Southern Poland). - Polish Journal of Ecology 59(2): 219-234.

Schmotzer A. (2015): Ceratocephala testiculata (Crantz) Roth és további adatok a Bükkalja flórájához. Kitaibelia 20(1): 81-142.

SchmotZer A., TAKÁcs A. \& Koscsó J. (2021): A newcomer from the east: naturalisation of Gypsophila perfoliata L. around Miskolc town (North-east Hungary). - Thaiszia 31(2): 171-194.

Sitzia T., KudRnovsky H., MüLler N. \& Michielon B. (2021): Biological flora of Central Europe: Myricaria germanica (L.) Desv. - Perspectives in Plant Ecology, Evolution and Systematics 52: 125629.

SÜVEGeS K., MolnÁR V. A. \& Koscsó J. (2017): A csermelyciprus (Myricaria germanica) új hazai előfordulása. - Kitaibelia 22(1): 60-63.

Süveges K., TAKÁcs A., NAgy T., Schmotzer A. \& Koscsó J. (2020): Florisztikai adatok a Tiszántúl északi pereméről II.: Borsodi-ártér és Sajó-Hernád-sík. - Kitaibelia 25(2): 169-186.

Turis P., Eliáš P., Schmotzer A., Király G., Schneider E., Kuciel H., Szewczyk M., Kozurak A., Antosyak T., VoloshchuK M., LAZAREvić P. \& LuSTYK P. (2014): Red list of vascular plants of the Carpathians. - In: Kadlečík J. (ed.): Carpathian red list of forest habitats and species (Draft). - The State Nature Conservancy of the Slovak Republic, pp. 44-105.

Virók V., Farkas R., Szmorad F. \& Boldoghné SzÛTS F. (2004): Florisztikai adatok Borsod-AbaújZemplénmegye északi részéről. - Kitaibelia 9: 143-150.

Vојткó A. (2001): A Bükk hegység flórája. - Sorbus 2001, Eger.

Beérkezett / received: 2022. 01. 04. • Elfogadva / accepted: 2022. 02. 22.

\section{Elektronikus melléklet / Electronic appendix}

Fig. e1 Slag mine excavation at Sásas valley near Miskolc (NE Hungary) (26.03.2021)

e1. ábra A miskolci Sásas-völgy salakbányája (2021.03.26.)

Fig. e2 False tamarisk on the wall of the slag mine (16.07.2021)

e2. ábra Csermelyciprus a salakbánya falán (2021.07.16.) 
KeLECSÉNYI Péter \& TAKÁCS Attila (2022):

New occurrence of Myricaria germanica in a secondary habitat (NE Hungary)

A Myricaria germanica újabb előfordulása másodlagos élőhelyen

Kitaibelia 27(1): 118-122.

DOI: $10.17542 /$ kit.27.010

Elektronikus melléklet / Electronic appendix

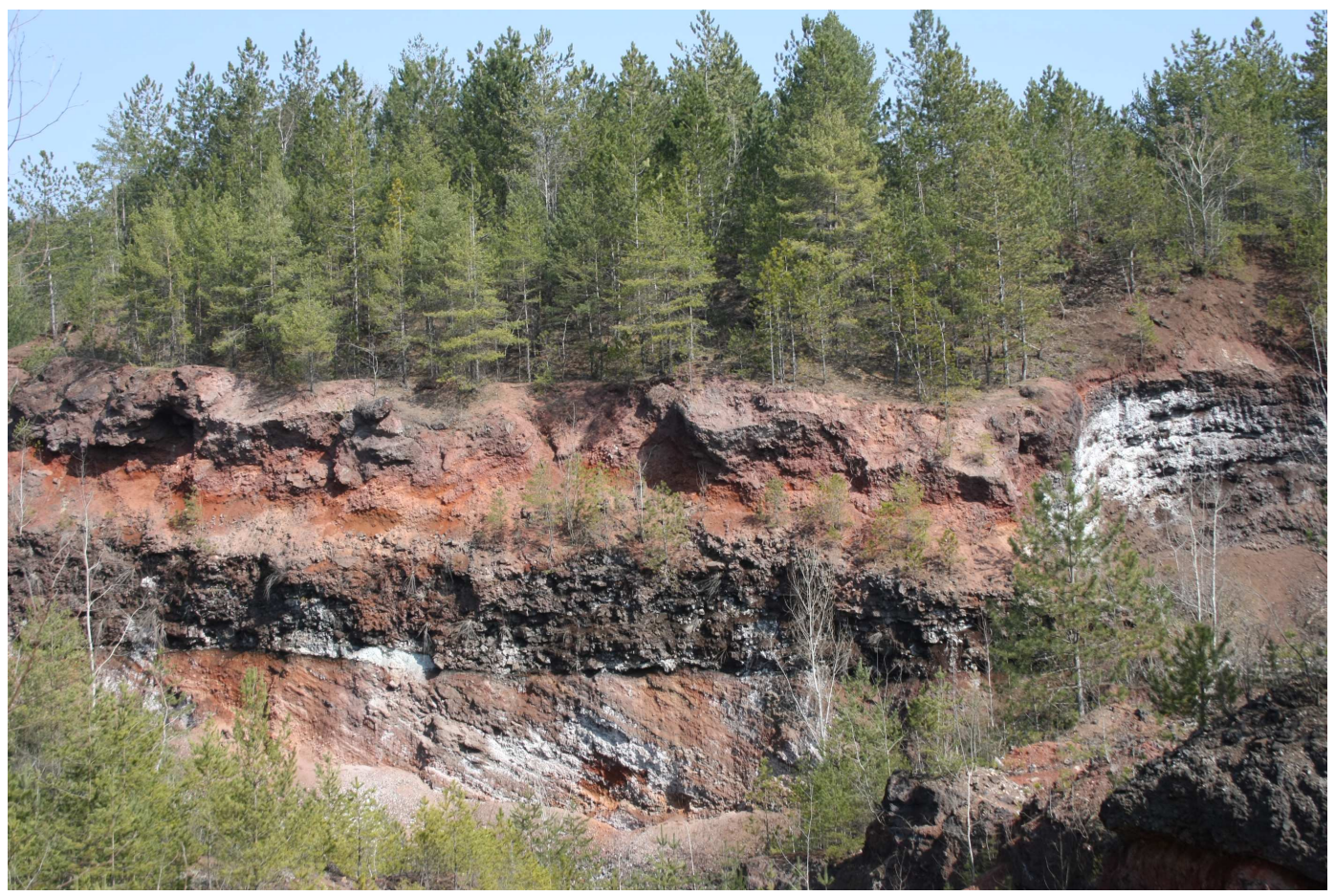

Fig. e1 Slag mine excavation at Sásas valley near Miskolc (NE Hungary) (26.03.2021) e1. ábra A miskolci Sásas-völgy salakbányája (2021.03.26.) 


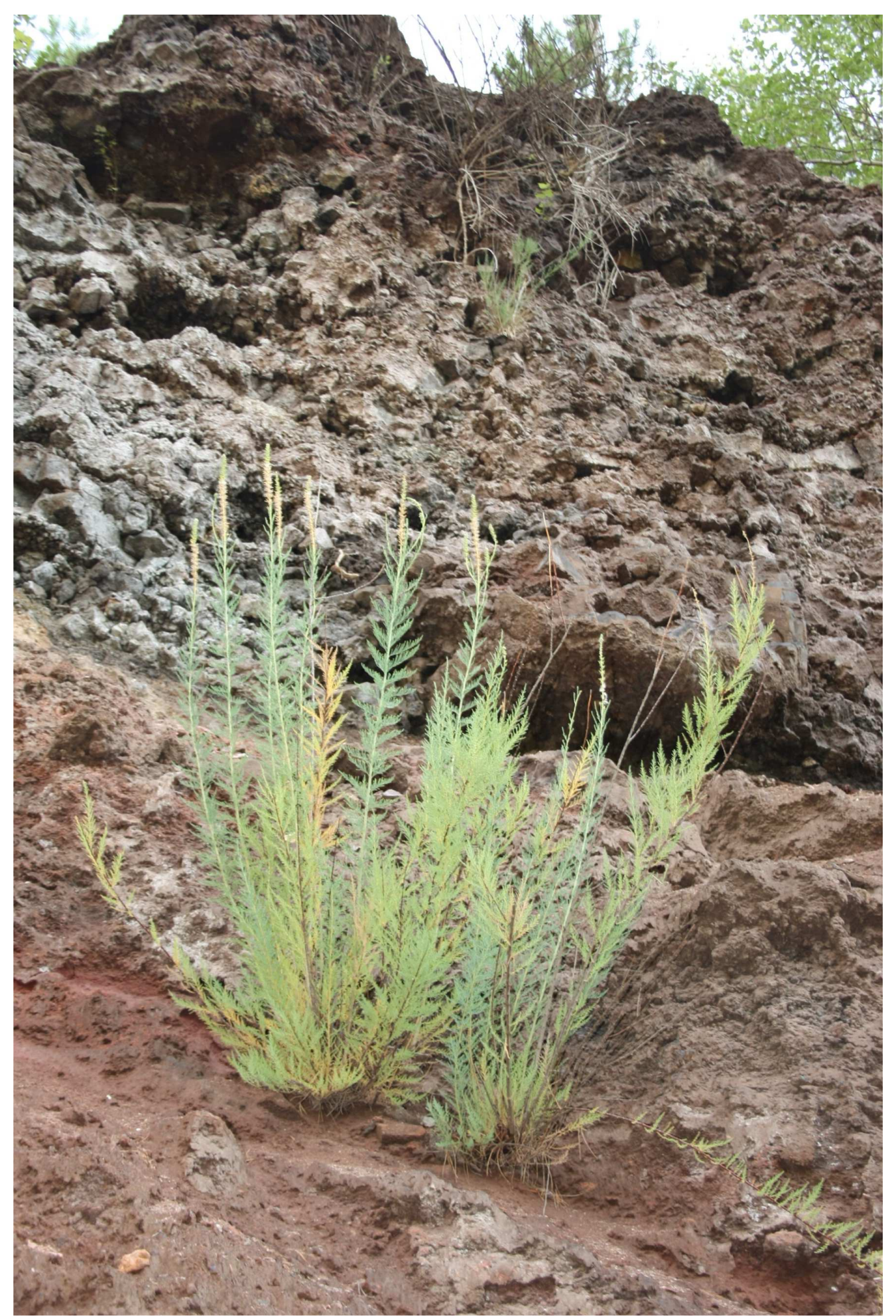

Fig. e2 False tamarisk on the wall of the slag mine (16.07.2021) e2. ábra Csermelyciprus a salakbánya falán (2021.07.16.) 